Doi: $10.15863 / \mathrm{TAS}$

International Scientific Journal Theoretical \& Applied Science

p-ISSN: 2308-4944 (print) e-ISSN: 2409-0085 (online)

Year: $2014 \quad$ Issue: $11 \quad$ Volume: 19

Published: $30.11 .2014 \quad$ http://www.T-Science.org
Anna Valerievna Iakovlieva

National aviation university, Ukraine pinchuk_anya@ukr.net

Oksana Aleksieievna Vovk

Dr. Sc., As. Prof., National aviation university,

Ukraine

o.a.vovk@mail.ru

Kazimierz Lejda

Dr Hab. Inż., Prof., Politechnika Rzeszowska, Poland

klejda@prz.edu.pl

Sergei Valerievich Boichenko

Dr. Sc., Prof., National aviation university, Ukraine chemmotology@ukr.net

Hubert Kuszewski

Dr. Inż., Politechnika Rzeszowska, Poland

hkuszews@prz.edu.pl

\title{
IMPROVEMENT OF TECHNOLOGICAL SCHEME OF FATTY ACIDS ETHYL ESTERS PRODUCTION FOR USE AS JET FUELS BIOCOMPONENTS
}

\begin{abstract}
The world tendency in replacement of traditional jet fuels with their alternative analogues is presented. The main technologies of jet biofuels production from plant oils are described. The main requirements to biocomponents used in jet fuels are formed. Chemical composition and properties of biocomponents produced via esterification of plant oils by ethanol were investigated. It was developed a method for physical-chemical properties of biocomponents improvemet. The efficiency of the proposed method is shown.

Key words: energy sources, jet fuel, biofuels, technology, esterification, fatty acids esters, physicalchemical properties.

Language: English

Citation: Iakovlieva AV, Vovk OA, Lejda K, Boichenko SV, Kuszewski H (2014) IMPROVEMENT OF TECHNOLOGICAL SCHEME OF FATTY ACIDS ETHYL ESTERS PRODUCTION FOR USE AS JET FUELS BIOCOMPONENTS. ISJ Theoretical \& Applied Science 11 (19): 44-50. doi: http://dx.doi.org/10.15863/TAS.2014.11.19.9
\end{abstract}

\section{Introduction}

Today, the main sources of energy are crude oil ( $40 \%$ of the world enegry use), natural gas $(23 \%)$, black and brown coal $(27 \%)$ [1, p. 3]. At the same time the world energy demand grows fastly. So, there is a need to replace oil with other feedstock, as it is a source of more than $90 \%$ of motor fuels. One of the main tasks in the field of production and use of aviation fuels and lubricants is to expand the resource base and to develop progressive technologies for the production of aviation fuels. Taking into account worsening state of environment it is necessary to use renewable and environmentally friendly and at the same time cheap raw materials [2, p. 5]. More over, alternative aviation fuels must meet a number of requirements related to efficiency, reliability and durability of aviation technics $[1$, p. $5 ; 2$, p. $4 ; 3$, p. 29].

Today numbers of international organizations, such as ICAO, IATA pay much attention to the questions of making civil aviation "green". One of the solutions of this task is implementation of alternative jet fuels. There was a proposal during the 38-th ICAO Assembly in November 2013 for "...collecting information on alternative kind of fuels development in aviation, presenting action plans of member states in order to obtain data about alternative jet fuels use in future and to estimate progress in achieving global goals of modern aviation" [4, p. 3]. As a result the alternative fuel task force group was created. The aim of this task group is to overview and to analize alternative kind of fuels, feedstock, conditions and amounts of their production.

Thus, search of methods and technologies of alternative fuels production from renewable feedstock is one of the key directions in solving such questions as energy-, resource saving and environmental safety in aviation.

\section{Literature overview}

Today, the technology of processing plant and (or) animal fat-containing feedstock is already widely known and applied. It involves the process of hydrogenation and deoxygenation of mono-, diand triglycerides of fatty acids, free fatty acids and fatty acid ethers with further application of 
hydrotreatment, hydrocracking, hydroisomerization and polymerization, isomerization and fractionation processes. The result is hydrogenated synthetic paraffin kerosene that can be added to conventional petroleum jet fuels in quantity up to $50 \%[1$, p. $5 ; 5$, p. 198]. This component is represented by synthetic kerosene fractions with properties similar to jet fuels. However, the described fuel component has certain disadvantages [3, p. 29]. By chemical structure it is a mixture of synthetic paraffinic hydrocarbons, and thus while getting into the environment, has a life cycle similar to traditional oil and causes negative effects on the environmental objects [6, p. 4].

Lately known, but not so common is the technology of plant oils or animal fats etherification [7, p. 113]. Methyl or ethyl alcohols are often used as agents of etherification, rarer butyl alcohol can be used $[1$, p. $6 ; 8$, p. 17]. As a result, a mixture of ethyl (methyl) esters of fatty acids is obtained. These biocomponents have become popular as a fuel substitute, especially for autotransport, mainly diesel fuel. In addition, except being an alternative to diesel fuel, fatty acid esters can be used as components for jet fuel.

Hypothesis - using fatty acids ethyl ethers of plant oils as a components of jet fuel may save crude oil deposits and increase physical-chemical, exploitation and ecological properties of fuels.

Object of investigation - technological scheme of jet fuels biocomponents production.

Subject of investigation - physical-chemical properties of biocomponents.

Aim - improvement of technological scheme for biocomponents production, that can be use as components of jet fuels.

Task

Development of methods and technologies of plant oil processing is generally based on theoretical and applied fundamentals of chemistry and chemical technology, organic synthesis, chemmotology and methodology of fuels \& lubricants properties investigation.

Today there is a great variety of methods for biofuel production from fatty acids ethyl (methyl) and rarely buthyl ethers [9, p. 240; 10, p. 115]. Generally, the most part of known methods were developed for biodiesel production. The experience of bioconponent use as additives to jet fuels is almost absent. The works $[11$, p. $53 ; 12$, p. $36 ; 13$, p. $47 ; 14$, p. 109] are theoretical and have overview character. Thus, the necessity in development new technology for obtaining biocomponent that can be used in jet fuels, became obvious.

\section{Technology of plant oil derived biocomponents production}

The technology of biocomponents production from plant oils is based on the reaction of oils esterification. The main components of oils are full complex ethers of glicerine and higher alyphatic (fatty) acids - triglycverides. The property of complex ether group of triglycerides is its ability to come into exchange reaction with acidic or alcohol groups - esterification reactions.

Esterification reactions are divided into three types: acidolysis, alcoholysis and reesterification [10, p. 256; 13, p. 138]. Acidolysis foresees reaction between triglyceride and acid; the exchange between acyl radicals and triglycerides takes place. As a result the new triglyceride is formed. It contains residuals of reacted acid and alcohol from initial ester. When the reaction goes between two different triglycerides the exchange reaction between their acyl groups is observed. Thus, the new triglycerides are formed. In case when alcohol is an esterification agent, the reaction is called alcoholysis. In a result of reaction between complex ester and alcohol the new complex ethers are formed. They contain alcohol radical and radical of initial ester acid. Other words, acyl radicals of ester are transferred to alcohol molecule. Today, etherification via alcoholysis is considered to be the most effective. Methanol and ethanol are the most popular alcohols for alcoholysis reaction $[1$, p. $6 ; 9$, p. $245 ; 15$, p. 36$]$; buthanol is used rarely $[10$, p. 147]. This work considers investigation of biocomponents obtained in a result of alcoholysis via ethanol.

Alcoholysis of triacylglycerides by ethanol occurs sequentially in three stages presented below. $[9$, p. $246 ; 14$, p. $108 ; 16$, p. 41]:

Triglyceride + ethyl alcohol diglycerine + fatty acid ethyl ester:

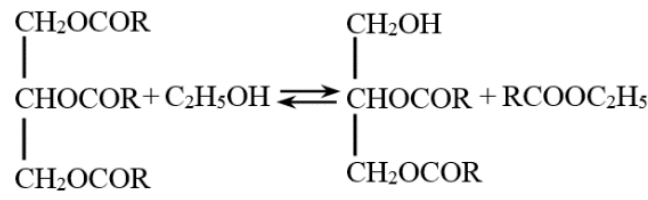

Diglyceride + ethyl alcoho monoglyceride + fatty acid ethyl ester:

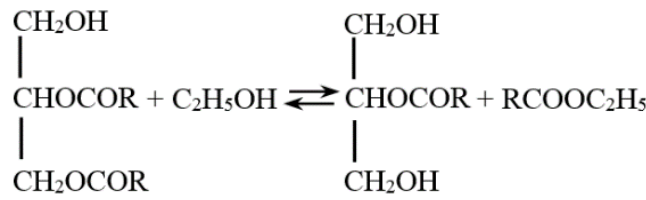

Monoglyceride + ethyl alcohol glycerine + fatty acid ethyl ester:

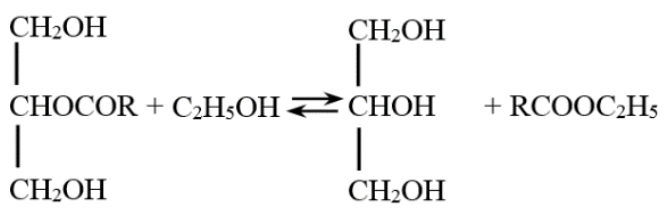


And the overall equation of alcohol exchange reaction:<smiles>CCOC(=O)C=CC(CC(=O)OCC)C(CO)CO</smiles>

Process of alcoholysis consists of step-by-step reactions with diglycerides and monoglycerides as intermediate products (formulas 1-4) [9, p. 247; 14, p. 108; 16, p. 41]. First stage is formation of diglycerides and ethyl ethers, than formation of monoglycerides and ethyl ethers, and at last formation of fatth acids ethyl esters (FAEE) and glycerine. All these stages are reversible, that is why the alcohol should be used in excessive amount. It is used to provide reaction in direction of ethyl esters formation up to $99,7 \%$. Ethyl ethers are diveded from phase acohol - catalyst during the reaction, and decrease at the same time the speed of reverse process.

Today, technology of fatty acids esters from plant oils became widely popular mostly for biodiesel production $[9$, p. $245 ; 10$, p. $286 ; 15$, p. $33 ; 17$, p. 2]. This technology is successfully realized both in laboratory conditions and at industrial installations of various scale. the main stages of technological process are: preparation of initial feedstock, preparation of reagent and catalyst, esterification itself, sedimentation, purification of ester layer and further processing of glycerine.There are many ways and methods for parameters optimization of the fatty acids ester production. They are described in details by the following authors: V.G. Semenov [9, p. 246], S.A. Nagornov [10, p. 270], M.B. Stepanov [15, p. 2], K.I. Patryliak [18, p. 3; 19, p. 3], and others.

For obtaining biocomponents of jet fuel we have proposed method, developed by the Institute of bioorganic chemistry and petrochemistry of the National Academy of Sciences of Ukraine [18, p. 3]. The peculiarity of this method is special initial preparation of alcohol and strictly defined parameters that provide self-division of reacting mixture into ester and glycerine parts. The main stages of the esterification process are shown at fig. 1.

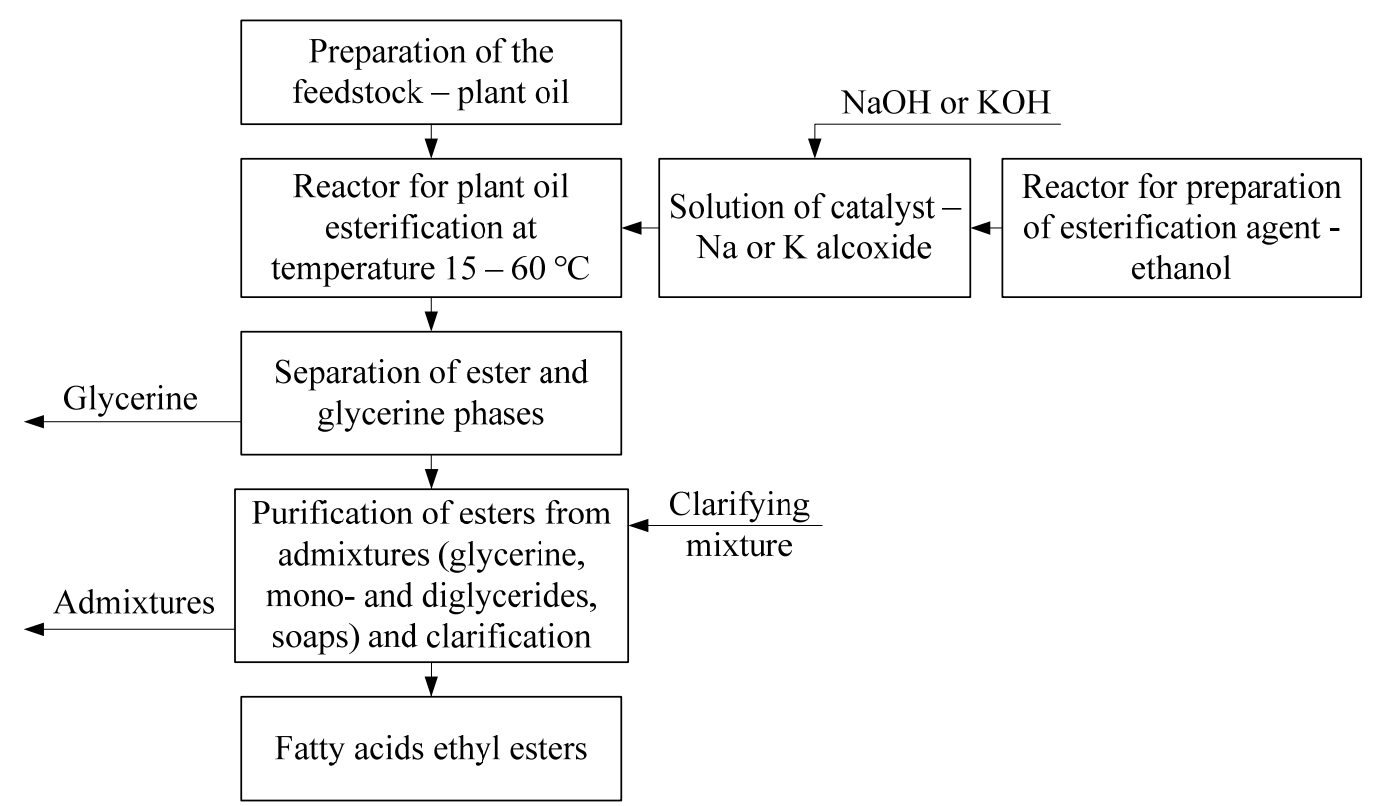

Fig. 1 - Principal block-scheme of biocomponents production by the method of plant oil esterification.

Investigation of component composition (table 1) and physical-chemical properties (table 2) have shown that the product obtained by described scheme contains a number of by-products: free alcohol, glycerine, incomplete esterification products (mono-, diglycerides), and sodium or potassium salts of fatty acids. Presence of these substances makes it impossible to use FAEE as components of jet fuels. The boiling temperature of ethanol $\left(78{ }^{\circ} \mathrm{C}\right)$ causes a decrease in boiling temperature of jet fuels that during the operation of aircraft adversely affect the processes of mixture formation and combustion [12, p. 17; 13, p. 139]. The content of glycerine, mono-, diglycerides of fatty acids and salts are also unacceptable in jet fuels, because of the negative impact on the process of combustion, low-temperature properties, increased sedimentation, and thus affect such exploitation property as pumpability [20, p. 307]. 
Component composition of FAEE mixture

Component composition of FAEE mixture
\begin{tabular}{|c|l||c||}
\hline \multicolumn{1}{|c|}{ Components } & Content, $\%$ \\
\hline \hline 1 & Total content of esters & 83,8 \\
\hline 2 & Monoglycerides & 1,1 \\
\hline \hline 3 & Diglycerides & 0,8 \\
\hline \hline 4 & Triglycerides & 0,73 \\
\hline \hline 5 & Glycerine, alcohol and other admixtures & 13,57 \\
\hline
\end{tabular}

Table 1

Table 2

Main physical-chemical properties of FAEE mixture

\begin{tabular}{|c|l|c|}
\hline \hline No & \multicolumn{1}{|c|}{ Property } & Actual value \\
\hline \hline 1 & Density at $\mathrm{t} 20^{\circ} \mathrm{C}, \mathrm{kg} / \mathrm{m}^{3}$ & 872 \\
\hline \hline 2 & Kinematic viscosity at $\mathrm{t} 20^{\circ} \mathrm{C}, \mathrm{mm}^{2} / \mathrm{s}$ & 7,4 \\
\hline \hline 3 & Freezing point, ${ }^{\circ} \mathrm{C}$ & minus 16 \\
\hline \hline 4 & Flash point, ${ }^{\circ} \mathrm{C}$ & 38 \\
\hline
\end{tabular}

Basing on results of our researches, theoretical and practical analysis of physical-chemical properties of feedstock for biocomponents production [21, p. 410], and analysis of complex of requirements to traditional jet fuels [22, p. 138] we have formed general requirements to the quality of FAEE that may be used further as a components of jet fuels :

- Optimal ratio of saturated and unsaturated hydrocarbon compounds in biocomponents;

- Compatibility of biocomponents with traditional jet fuel;

- Physical stability of biocomponent and jet fuel mixtures that is provided by their mutual solubility;

- Low density that influence on the level of evaporability, fuel-air mixture formation and provide completeness of fuel combustion;

- Satisfactory low-temperature properties that provide reliable exploitation at temperatures below zero;

- Low viscosity that provides fuel pumpability and reliability of fuel system work at temperatures below zero;

- Sufficient heat of combustion that characterizes fuel expence and determines дальність о flight.

- Chemical and thermal oxidation stability with minimal suspectability to form sediments in fuel system of jet engine;

- Absence of production by-products, water and other admixture in composition of biocomponents;

Thus, we have concluded that biocomponents obtained by the scheme at fig. 1, can not be used directly in jet fuels. Other words, we have to improve the tecnology in order to obtain biocomponents of higher quality.

Improvement of the technology of biocomponents production

Today, scientist are actively researching ways to improve the quality of biofuels. There is a method of biofuels modifying. The essence of this method is adding to biofuels organic esters of aliphatic acids and alcohols of smaller molecular weight $[11$, p. 57]. This method is very effective, but the main difficulty is to ensure a sufficient quantity of feedstock for the implementation of this method on an industrial scale.

Also the method of pant oils transesterification is known. It involves the reaction of the double exchange between oils triglyceride and low molecular weight esters - alkyl acetates [14, p. 110]. Studies show that organic products have received good low-temperature properties. However, in addition to the desired product, they contain significant amounts of undesirable components. In addition, it is necessary to study the cost-effectiveness of this method.

We have used the classical method of thermal distillation, which is widely and effectively used in modern chemical technology. Today, vacuum distillation, molecular distillation and distillation in thin films are considered to be the most facile methods of thermal distillation [23, p. 89; 24, p. 379]. Vacuum distillation or vacuum fractionation is the easiest in implementation. General principle of fractionation is separation of the mixture by a reason of different boiling temperature of components. The essence of this method lies in the distillation (separation) of the liquid at the vacuum distillation installation at decreased pressure. As the 
most of oil esters start boiling at a temperature about $300{ }^{\circ} \mathrm{C}$ and subjected to chemical distrucion at higher temperatures, the process of vacuum fractionation is carried out at the vacuum distillation installation at a pressure of $0,5-0,7 \mathrm{kPa}$. It avoids chemical destruction of FAEE molecules that occurs during atmospheric distillation [25, $\mathrm{p}$. $290 ; 26$, p. 340]. In such way the better level of biocomponents purification is reached. In general, there are three main stages of the process:

- Separation of ethyl alcohol at early distillation stage;
- Distillation of pure fatty acid esters. Since they are compounds of one class, most of them boil in a fairly narrow temperature range $\left(355-380^{\circ} \mathrm{C}\right)$.

- Separation of nonliquid residue which remains after distillation process.

The main product obtained in a result of vacuum fractionation, ie biocomponents is additionally filtered and then it is suitable for use as a component of jet fuels. Proposed method of biocomponents properties improvement is schematically shown in figure 2.



Fig. 2 - Improved scheme of biocomponents production by vacuum distillation. 
Effectiveness of the developed method of FAEE properties improvement is presented in tables 3 and 4 . The component composition of FAEE mixture, obtained by techological process presented at fig. 1 and improved process. (fig.1) as well as their physical-chemical properties are presented.

Improvement of FAEE mixture composition after vacuum distillation

\begin{tabular}{|c|c|c|}
\hline $\begin{array}{|lc|}\text { Components } & \text { Sample } \\
\end{array}$ & $\begin{array}{c}\text { Content in mixture of } \\
\text { FAEE, \% }\end{array}$ & \begin{tabular}{|c|} 
Content in mixture of FAEE \\
after vacuum distillation
\end{tabular} \\
\hline Total content of esters & 83,8 & $<99$ \\
\hline Monoglycerides & 1,1 & - \\
\hline Diglycerides & 0,8 & - \\
\hline Triglycerides & 0,73 & - \\
\hline Glycerine, alcohol and other admixtures & 13,57 & $>1$ \\
\hline
\end{tabular}

Improvement of FAEE mixture properties after vacuum distillation

\begin{tabular}{|c|c|c|}
\hline \begin{tabular}{|lc} 
Components & Sample \\
\end{tabular} & $\begin{array}{c}\text { Content in mixture of } \\
\text { FAEE, \% }\end{array}$ & \begin{tabular}{|c|} 
Content in mixture of FAEE \\
after vacuum distillation
\end{tabular} \\
\hline Density at $\mathrm{t} 20^{\circ} \mathrm{C}, \mathrm{kg} / \mathrm{m}^{3}$ & 872 & 869 \\
\hline Kinematic viscosityat t $20^{\circ} \mathrm{C}, \mathrm{mm}^{2} / \mathrm{s}$ & 7,4 & 7,27 \\
\hline Freezing point, ${ }^{\circ} \mathrm{C}$ & minus 16 & minus 18,5 \\
\hline Flash point, ${ }^{\circ} \mathrm{C}$ & 38 & 186 \\
\hline
\end{tabular}

As it is seen from the tables, FAEE mixture after treastment all most doesn't contain such undesirable components as alcohol, glycerine, mono-, di-glycerides, free fatty acids and other admixtures. Thus the quality of the final product significantly increases.
So, improving of technology of biocomponents production by vacuum distillation allows using them as components for jet fuels. This method has several advantages over other known methods. It is quite easy in implementation, besides it doesn't require the use of additional reagents that increase the cost of the product.

\section{References:}

1. Daggett DL, Hendricks RC, Walther R, Corporan E (2007) Alternate Fuels for use in Commercial Aircraft. The Boeing Company: 8 .

2. Kirillov NG, Lazarev AN (2010) Ekologiia i avtotransport: O neobhodimosti perehoda na prirodnii gaz kak perspektivnoe motornoe toplivo. AvtoGazoZapravochnii Komplex + Alternativnoe toplivo, No. 4 (52), pp. 4-10.

3. Ustymenko V (2008) Pytannya energozabezpechennya avtotransportu Ukraini v umovah svitivoi energetychnoi kryzi. Pereviznik UA. No. 15/2008. pp. 28-30.

4. (2013) ICAO Assembly — 38th Session. Report of The Executive Commitee on Agenda. Item 17. A38-WP/429. P/43. 2/10/13
5. Boichenko SV, Cherniak LM, Iakovlieva AV (2013) Tradiciini tehnologii vyrobnictva paliv dlia povitriano-reactivnih dvyguniv. Visnik Natsionalnogo aviatsiinogo universytetu. No. 2 (55), pp. 195-209.

6. An American National Standard ASTM D7655 Standard Specification for Aviation Turbine Fuel Containing Synthesized Hydrocarbons

7. Iakovlieva A, Boichenko S, Gay A (2014) Cause-Effect Analysis of the Modern State in Production of Jet Fuels. Journal of Chemistry \& Chemical Technology, Vol. 8, No. 1, pp. 107-116.

8. Markov VA, Devianin SN, Nagornov SA (2013) Rabota transportnogo dizelia na 
smesiah dizelnogo topliva I metilovogo efira podsolnechnogo masla. Transport na alternativnom toplive, № 3 (33).

9. Pramanik K (2003) Properties and use of jatropha curcas oil and diesel fuel blends in compression ignition engine. Renewale energy, Vol. 28, Iss. 2, pp. 239-248.

10. Devianin SN, Markov VA, Semenov VG (2007) Rastitelnie masla I topliva na ih osnove dlya dizelnih dvigatelei: monografia. - H.: Novoe slovo, 452.

11. Nagornov SA, Dvoretskii DS, Romancova SV, Tarov VP (2010) Tehnika i tehnologii proizvodstva i pererabotki rastitelnih masel: posobie. Min-vo obrazovaniia i nauki Ros. Federacii, Tambov. gos. tehn. un-t. - Tambov: izd-vo GOU VPO TGTU, 96.

12. Danilov AM, Kaminskii EF, Havkin VA (2003) Alternativnie topliva: dostoinstva i nedostatki. Problem primeneniia. Rossiiskii himicheskii zhurnal, t. XLVII, No. 6.

13. Braginskyi OB (2008) Alternativnie motornie topliva: mirovie tendencii i vibor Rossii. Rossiiskii himicheskii zhurnal, t. LII, No.6, pp. 137-146.

14. Yanovskii LS, Fedorov EP, Varlamova NI, Bodorako PV, Popov IM (2009) Alternativnie reaktivnie topliva: problem i perspektivi. Vestnik NAU, No. 1, pp. 108-112.

15. Stepanov MB, Vasylkevich OI, Yushchenko OV, Potapov MM, Potapov OM (2008) Patent Ukraini №35402 vid 10.09.2008, Bul. No. 17 Sklad komponenta paliva otrimanogo izsirovini roslinnogo pohodzhennya.

16. Kirichenko VI, Boichenko SV, Kirichenko VV, Nezdorovin VP (2013) kompleksnaia pererabotka tehnicheskih rastitelnih masel: koncepciya, metodi i tehnologii. Energotehnologii i resursosberezhenie. - K. No. 4, pp. 31-40.

17. Krylov IF, Emeljanov VE (2008) Alternativnie motornie topliva. Proizvodstvo primenenie, perspectivi. Mir nefteproductov. No. 1, pp. 38-42.
18. Patryliak LK, Kuhar VP, Patryliak KI, Ohrimenko MV, Manza IA, Voloshina JG, Iakovenko AV, Ivanenko VV, Hranovska VI, Petrovich VV (2008) Patent Ukraini №35913 vid 10.10.2008, Bul. № 19 Sposib oderzhannia biodizelnogo paliva etanolnoju pereesterifikacieju zhiriv. Institut bioorganichnoi himii ta naftohimii NAN Ukraini.

19. Patryliak LK, Patryliak, Ivanenko VV, Ohrimenko MV, Voloshina JG, Manza IA, Konovalov SV, Hranovska VI (2012) Patent na vinahid № 98281 Ukraine vid 25.04.2012, Bul. № 819 Sposib oderzhannia biodizelnogo paliva shliahom pereesterifikacii trigliceridiv etanolom na katalizatori.

20. Boichenko SV, Vovk OO, Iakovlieva AV (2013) Overview of innovative technologies for aviation fuels production. Journal of Chemistry and chemical technology. Vol. 7, No. 3, pp. 305-312.

21. Tutunnikov BN, Buhshtab BI, Gladkii FF, etc. (1992) Himiia zhirov. Moscow, Kolos: 448.

22. Yu F, Deng S, Chen P, Liu Y, Wan Y, Olson A, Kittelson D, Ruan R (2007) Physical and Chemical Properties of Bio-Oils From Microwave Pyrolysis of Corn Stover. Applied Biochemistry and Biotechnology. Vol. 136, 140.

23. Iakovlieva AV (2013) Doslidgennia vlastyvostei olii jak syrovini dlia otrymannia compnentiv aviatsiinogo paliva. Voprosi himii i himicheskoi tehnologii. No. 4, pp. 86-93.

24. Yanovskii LS, Dmitrenko VP, Dubrovkin NF (2005) Osnovi aviatsionnoi himmotologii. Moscow, MATI: 680.

25. Keri F, Sandberg R (1981) Uglublennii kurs organicheskoi himii. T.2. Reakcii i sintezi. Moscow, Himiia: 456.

26. Bekker G, BergerV, Domshke G, Fanghenel E, etc. (1979) Organikum. Praktikum po organicheskoi himii. T.1-2, Moscow, Mir: 453. 